\title{
Angiomyxoma Presenting as an Unusual Vaginal Mass
}

\author{
IP ALAM ${ }^{\mathrm{a}}$, Z PERVIN ${ }^{\mathrm{b}}$, FB MONAYEM ${ }^{\mathrm{c}}$
}

\begin{abstract}
Summary:
Angiomyxoma is a rare tumour which arises from pelvis. $A$ case of an Angiomyxoma of vagina in a 35year old lady is reported. The patient was presented with a mass about $7 \times 8$ cm coming down through introitus and urinary discomfort.
\end{abstract}

\section{Introduction:}

Angiomyxoma is a rare slow growing and soft and benign tumour that predominantly affects in the perineum of women in reproductive age. ${ }^{1}$ It can be mistaken both clinically and microscopically for several other conditions. Here we report a rare case of aggressive anxiomyxomawhich was present in Faridpur Medical College Hospital,Faridpur, Bangladesh.

\section{Case Report:}

A 35 years old lady presented in Gynaecology outpatient department with the complaints of a mass in introitusand something coming down per vagina for 5-6 months. She also noticed burning sensation and difficulty in passing urine for last few days. Patient was dumb, separated from husband and poor lady. The mass was gradually increasing in size and attain a big size within six months with a pressure sensation in introitus. When she developed unbearable complication her relatives brought her in hospital. She had one child, age about 17years. On examination there was a mass about $7 \times 8 \times 8 \mathrm{cmprotruding}$ through introitus, which was soft and irregular consistency but with a shiny smooth surface. It was neither uterus, nor a polyp and could not reducible,but it was pushed into introitus manually. USGshows a small myoma in uterus and a growth of about $7 \times 8 \mathrm{~cm}$, but the origin of mass could not mentioned. As there was urinary complication Intravenous urography was done. It shows

a. Dr. Irin Parveen Alam, Assistant Professor, Dept. of Obstetrics \& Gynae, Faridpur Medical College Hospital, Faridpur.

b. Dr. Zebunnesa Pervin, Associate Professor, Dept. of Obstetrics \& Gynae, Faridpur Medical College Hospital, Faridpur.

c. Dr. Farhana Binte Monayem, Assistant Registrar, Dept. of Obstetrics \& Gynaecology, Faridpur Medical College Hospital.

Address of Correspondence: Dr. IrinParveenAlam, Assistant Professor, Dept. of Obstetrics \& Gynae, Faridpur Medical College Hospital, Faridpur, Mobile: 88-01715348398, E-mail: dririn.alam@yahoo.com

Received: 8 October, 2013

Accepted: 15 May, 2014
Mass was dissected out and Histopathological examination revealed angiomyxoma. Though it is a rare tumour it is clinically misdiagnosed with vaginal polyp, vaginal cyst or inversion of uterus.

(J Banagladesh Coll Phys Surg 2014; 32: 229-230)

filling defect in urinary bladder due to pressure effect of the mass. As it was not certain about the origin of the mass, at first laparotomy and total abdominal hysterectomy was done. While opening the vault a fairly big mass could palpated seems to originate from vagina. Then the mass was removed per vaginal route by giving incision on anterior vaginal wall. It was non capsulated, solid nodular lobulated yellow-bluish lipoma like structure. Histopathological report revealed the mass as anxiomyxoma.

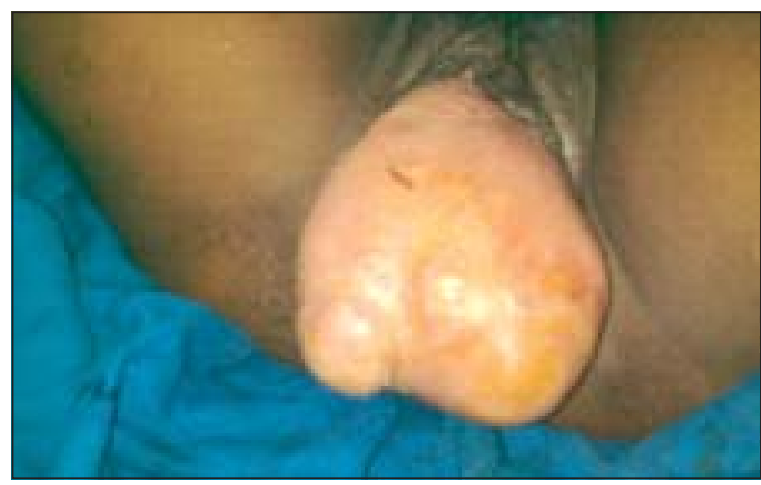

Fig.-1: Unusual mass protruding through introitus.(Printed with permission)

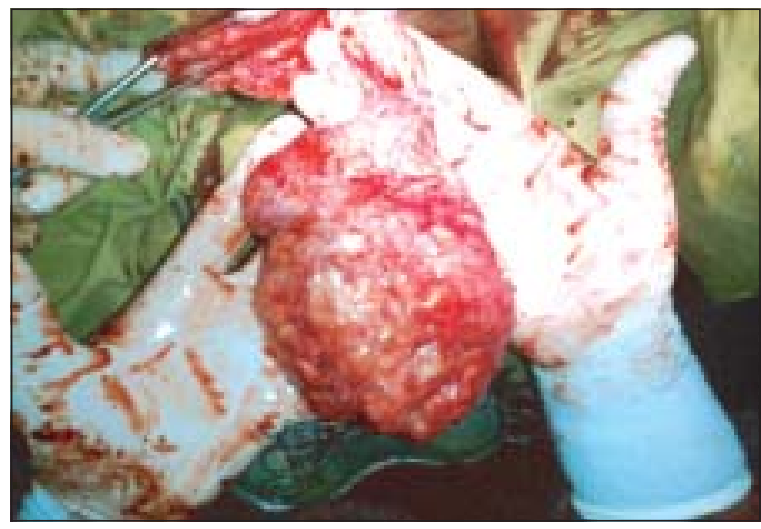

Fig.-2: Mass during dissection 


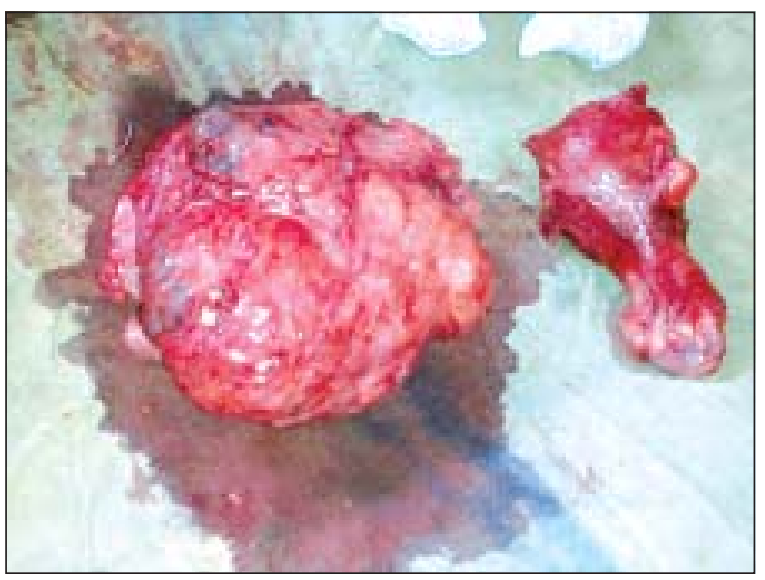

Fig.-3: Massand the uterus after hysterectomy

\section{Discussion:}

Anxiomyxoma is an uncommon tumour which predominantly grows in pelvic and perineal region in female ${ }^{2}$. The age distribution is wide and peak incidence is at 31-35years. Male to female ratio is $6: 1^{1}$. These large sized tumours areslow growing and painless. The presenting features are nonspecific. It may present as a palpable mass or heaviness and discomfort in lowerabdomen or vulva ${ }^{3}$. It may be clinically misdiagnosed as inguinal hernia or a bartholin cyst, cervical polyp, vaginal polyp, myxoma, lipoma, vulval mass, Gartner's duct cyst or vaginal prolapsed. ${ }^{4}$. The term "aggressive anxiomyxoma” was designated to the neoplasm to emphasize the neoplastic nature of the blood vessels and its tendency to be locally aggressive and recur after treatment. Recurrence rates up to $70 \%$ have been reported. So long term follow-up of the patient is necessary ${ }^{5}$.

The patient had difficulty in urination which is a common symptom in urinary tract infection. When a female patient come with such symptom a detailed history and examination is necessary. A simple pelvic examination may reveal the cause ofdysuria in some case.Physical examination including specular examination of the vagina and urethra may reveal causes of dysuria that are not related to urinary tract infections ${ }^{6}$.

Because of its propensity to occur in female patients during reproductive years, it is possible that aggressive angiomyxoma is a hormonally responsive neoplasm. ${ }^{7}$.Surgical excision is the treatment of choice in most of the times.In some cases removal of the tumour is difficult due to local infiltration and adjuvant therapy may be used. Treatment options include use of hormonal manipulation, such as tamoxifen, raloxifen or $\mathrm{GnRH}$ analogs, radiotherapy and arterial embolisation. ${ }^{6}$.

It often recurs and there is no correlation between the size of the tumors and the chance of recurrence.The tumor has widely been known that have no potential to metastasize. But some recent reports arecontrary to this knowledge. ${ }^{8}$

\section{Conclusion:}

Anxiomyxoma is a benign mesenchymal tumor occurring in young females of reproductive age. The patient may present with alump or urinary symptom which should be carefully evaluated. Medical history, physical examination and finally histopathological examination can help the diagnosis of the condition.

\section{References:}

1. Steeper TA, Rosai J. Aggressive angiomyxoma of the pelvis andperineum: report of nine cases of a distinctive type ofgynaecologic soft tissue neoplasm. Am J ClinPathol 1983; 7:453.

2. Behrnwala KA, Thomas JM. Aggressive angiomyxoma: A distinct clinicalentity. Eur J SurgOncol 2003; 29: 559-563.

3. Akbulut M, Nese Ç. Demirkan,Çolakoglu N, Düzcan E.Aggressive angiomyxoma of the vulva: A case report andreview of the literature. Aegean Pathology Journal 2006; 3: $1-4$.

4. Gungor T, Zengeroglu S, Kaleli A, Kuzey GM. Aggressiveangiomyxoma of the vulva and vagina. A common problem:misdiagnosis. Eur J ObstetGynecolReprodBiol 2004; 112:114-116.

5. RoggenJF,Unnik JA, Briare IH, Hongendoorn PC, Aggressive anxiomyxoma: A clinicopatholological and immunohistochemical study of 11 cases with long term follow-up, Virchows Arch 2005;446:157-63.

6. Paplomata E,Fotas A, Balaxis D, Filindris T, Charalambous S, Rombis V Aggressive angiomyxoma mimicking cervical polyp Pelviperineology 2010; 29; 30-31.

7. Blandamura S, Cruz J, Faure Vergara L, Machado Puerto I,Ninfo V. Aggressive angiomyxoma: a second case of metastasiswith patient's death. Hum Pathol 2003; 34: 1072-1074. 